\title{
Curative Effect of Ascorbic Acid and Gibberellic Acid on Wheat (Triticum astivum L.) Metabolism under Salinity Stress
}

\author{
Neelambari $^{1^{*}}$, Chetanaben Mandavia ${ }^{2}$ and S. Sree Ganesh ${ }^{3}$ \\ ${ }^{1}$ Department of Botany and Plant Physiology, Dr. Rajendra Prasad Central Agricultural \\ University, Pusa, Bihar, India \\ ${ }^{2}$ Department of Genetics and Plant Breeding, Junagadh Agricultural University, \\ Gujarat, India \\ ${ }^{3}$ Department of Genetics and Plant Breeding, Navsari Agricultural University, Gujarat, India \\ *Corresponding author
}

\section{A B S T R A C T}

An alternative strategy to ameliorate salt stress could be to use exogenous application of

Keywords

Salt stress, Ascorbic acid, Gibberellic acid and polyphenol oxidase

Article Info

Accepted:

04 December 2017

Available Online:

10 January 2018 plant growth stimulators. The present investigation was carried out to study the effects of hormonal priming with ascorbic acid and gibberellic acid on wheat (Triticum astivum L.) metabolism during germination phase under saline conditions. Seeds of wheat var. GW496 were pre-soaked in three levels each of ascorbic acid (AsA) viz., (50, 100 and $150 \mathrm{mg}$ $\left.\mathrm{L}^{1}\right)$ and gibberellic acid $\left(\mathrm{GA}_{3}\right)$ viz., $\left(150,200\right.$ and $\left.250 \mathrm{mg} \mathrm{L}^{-1}\right)$ for 2 hrs under salinity stress given by treating with $\mathrm{NaCl} @ 50,75$ and $100 \mathrm{mM}$ with four replications. The result showed that seeds primed with $100 \mathrm{mg} \mathrm{L}^{-1}$ AsA and $250 \mathrm{mg} \mathrm{L}^{-1} \mathrm{GA}_{3}$ effectively enhances seed moisture content, germination percentage, germination index, root/shoot length ratio, root/ shoot fresh weight ratio and vigour index I. However, among biochemical parameters application of $100 \mathrm{mg} \mathrm{L}^{-1} \mathrm{AsA}$ and $150 \mathrm{mg} \mathrm{L}^{-1} \mathrm{GA}_{3}$ enhanced proline content. Seeds primed with $100 \mathrm{mg} \mathrm{L}^{-1} \mathrm{AsA}$ and $250 \mathrm{mg} \mathrm{L}^{-1} \mathrm{GA}_{3}$ effectively enhanced polyphenol oxidase activity. It could be concluded that, pretreatment of wheat cultivar with AsA and $\mathrm{GA}_{3}$ could partially alleviate the harmful effect of salinity by increasing vigour, antioxidative enzymes activity and accumulation of osmolytes.

\section{Introduction}

Wheat is a major renewable resource for food and industrial raw materials, and among major crops grown on the largest area worldwide. Wheat is the most widely grown crop worldwide grown over 200 million ha and the second most abundant staple crop grown worldwide providing globally $20 \%$ of all food calories. Salinity is one of the major and increasing problems in irrigated agriculture in India and world, particularly in wheat grown areas. Approximately $7 \%$ of worlds land area, $20 \%$ of the worlds cultivated land and nearly $50 \%$ of the irrigated land is affected by salt stress as reported by Abdelfattah et al., (2009). In India, total salt affected area is 12 million ha Abdul et al., (1973). Salinity affects almost 
every aspect of the physiology and biochemistry of plants and significantly reduces yield. The effect of salinity on plant may cause disturbance in plant metabolism as reported by El-Tayeb et al., (2005). It was also reported that seed germination, one of the most critical phases in plant life, is greatly affected by salinity Abo-Kassem (2007), which either induces a state of dormancy at low levels or completely inhibits germination at higher levels Iqbal et al., (2006).

Plant hormones are active members of the signal cascade involved in the induction of plant stress responses (Pedranzani et al., 2003). The exogenous application of gibberellic acid $\left(\mathrm{GA}_{3}\right)$ improved tolerance under abiotic stress by induction and increasing of the endogenous levels of salicylic acid (Alonso- Ramírez et al., 2009). Gibberellic Acid $\left(\mathrm{GA}_{3}\right)$ is the most important growth hormone which increases cell growth and elongation, cell division in cambial zone, breaks seed dormancy, promotes seed germination, intermodal length, hypocotyls growth, increases the size of leaves, enable greater photosynthesis and plant metabolism and ultimately increases plant or crop yield under normal as well stress condition. Gibberellic acid has been reported to increase germination percentage and seedling growth and overcome the preventive effects of the salt stress on germination (Kabar and Baltepe, 1987). Hence, the present investigation was carried out in order to investigate the extent of effectiveness of these two in ameliorating the adverse effect of salinity stress. Ascorbic acid (AsA) is regarded as one of the most effective growth regulators against abiotic stresses Batool el al., (2012). Azooz et al., (2013) showed that application of ascorbic acid through seed soaking enhanced plants growth by increased germination percentage, root and shoot fresh and dry weights, chlorophyll content and higher accumulation osmolytes. Experimental studies on different plants have shown that pretreatment with AsA reduced salt induced adverse effects and resulted in a significant increment of growth and yield Batool el al., (2012).

\section{Materials and Methods}

\section{Experimental materials}

Seed of wheat cultivar GW-496, ascorbic acid (AsA), gibberellic acid $\left(\mathrm{GA}_{3}\right)$ and sodium chloride $(\mathrm{NaCl})$

\section{Treatment}

The experiment was carried out with four replications, 100 (25 seeds in each replica) seeds were soaked in distilled water (control), three concentrations of ascorbic acid (AsA) viz., (50, 100 and $150 \mathrm{mg} \mathrm{L}^{-1}$ ) and three concentrations of gibberellic acid $\left(\mathrm{GA}_{3}\right)$ viz., (150, 200 and $250 \mathrm{mg} \mathrm{L}^{-1}$ ) solutions for $2 \mathrm{hrs}$ and then the same were treated with $2.5 \mathrm{~g} / 1$ thiram for about 2 minutes. For germination, 25 seeds from each sample were spread in Petri dishes over Whatman No.1 filter paper. The sufficient volume $(10 \mathrm{ml}$ from $1 \mathrm{st}$ to 5 th day and $20 \mathrm{ml}$ from 5th to 11th) of $\mathrm{NaCl}$ concentrations (50 mM, $75 \mathrm{mM}$ and $100 \mathrm{mM}$ ) were added to induce salinity stress, whereas distilled water was provided as control.

\section{Physiological Analysis}

\section{Germination percentage}

Germination percentage was recorded at 24, 48, 72, 96 and $120 \mathrm{~h}$ after pre-soaking treatment. It was calculated as per ISTA (International Seed Testing Association) rules 1985 with the following formula:

Number of seeds germinated (At a particular time)

Germination percentage $=----------------\times 100$

Total number of seeds taken for germination 


\section{Germination index}

Germination index was recorded at $24 \mathrm{~h}$ after pre-soaking treatment. It was calculated as per formula given by Maguire (1962), using average value derived from germination trial and finally the replication means are presented.

Increase in germination \% over time Germination index $=$

Change in time in day

\section{Seed moisture percentage}

Seed moisture was recorded at $24 \mathrm{~h}$ after presoaking treatment.

(Actual sample weight - oven dry weight) Seed moisture \% = --------------- $\times 100$ Actual sample weight

\section{Root to shoot length ratio}

Root / shoot length ratio was recorded at $11^{\text {th }}$ day after germination (DAG).

Root length in $\mathrm{cm}$

Root $/$ shoot length ratio $=$-----------------

\section{Root/ shoot fresh weight ratio}

Root/shoot fresh weight ratio was recorded at $11^{\text {th }}$ day after germination (DAG).

Root fresh weight in $\mathrm{g}$ Root $/$ shoot fresh weight ratio $=$

Shoot fresh weight in $\mathrm{g}$

\section{Vigour index I}

Vigour index- I was recorded at $11^{\text {th }}$ day after germination. A combination of standard germination percent with seedling length provides evaluation of seedling vigour index.
It was calculated as per procedure prescribed by Abdul-Baki and Anderson (1973), as under

Vigour index $-\mathrm{I}=$ Germination percent $x$ Seedling mean length

\section{Biochemical Analysis}

\section{Polyphenol oxidase activity}

The estimation of Peroxidase activity was determined as per the methods suggested by Malik and Singh, (1980): Leaves (0.5 g) were extracted in mortar and pestle motor pastor and homogenized in $50 \mathrm{mM}$ sodium phosphate buffer ( $\mathrm{pH}$ 7.0) containing $1 \%$ soluble polyvinyl pyrolidine (PVP). The homogenate was centrifuged at $13,000 \mathrm{x} \mathrm{g}$ for $15 \mathrm{~min}$ at $4^{\circ} \mathrm{C}$ and the supernatant used for assays of the activities of POD. The activity of POD was assayed by adding aliquot of the tissue extract $(100 \mu \mathrm{L})$ to $3 \mathrm{~mL}$ of assay solution, consisting of $3 \mathrm{~mL}$ of reaction mixture containing $13 \mathrm{mM}$ guaiacol, $5 \mathrm{mM} \mathrm{H}_{2} \mathrm{O}_{2}$ and $50 \mathrm{mM} \mathrm{Na}$ phosphate $(\mathrm{pH}$ 6.5). An increase in optical density at $470 \mathrm{~nm}$ for $1 \mathrm{~min}$ at $250 \mathrm{c}$ was recorded using spectrophotometer. POD activity was expressed as change in absorbance $\mathrm{min} / \mathrm{mg} /$ protein.

\section{Statistical analysis}

Data analysis was performed using techniques of analysis of variance (ANOVA) with the statistical software -DSAASTAT (Version 1.101). Mean separations were performed by Duncan's Multiple Range Test (DMRT) at 5\% level.

\section{Results and Discussion}

\section{Germination percentage}

The germination percentage decreased remarkably with increasing salinity levels. Salinity stress at the mild level posed a little 
reduction on the germination percentage however; a drastic reduction was observed at moderate and severe stress conditions. Similarly, the increasing salt stress levels with substantial decrease in overall germination percentage was reported by Akbarimoghaddam et al., (2011) and Datta et al., (2009) in wheat. The observed decrease in germination percentage may be attributed to the decrease in osmotic potential, increasing toxic ions, changing the remobilization balance of seeds reservoirs, loss of viability at higher salinity level and reduced water imbibitions. In addition high salinity delayed radical emergence and decreased germination percentage.

A marked increase in germination percentage was found after pretreatment of wheat seeds with ascorbic acid and gibberellic acid under saline condition. In case of AsA treated wheat seeds at 24, 48, 72 and $96 \mathrm{~h}$ under all three salt stress levels its concentration of $100 \mathrm{mg} \mathrm{L}^{-1}$ exhibited the highest germination percentage.. At $120 \mathrm{~h}$ all treatment of AsA performed equally as $100 \%$ (data in parenthesis) germination was achieved. Similar observation was proposed by Afzal et al., (2006) in wheat and Behairy et al., (2012) in fenugreek.

Treatment of wheat seeds with $\mathrm{GA}_{3}$ at 24, 48, and $72 \mathrm{~h}$ under mild, moderate and severe stress condition treatment with $\mathrm{GA}_{3}$ @ $250 \mathrm{mg}$ $\mathrm{L}^{-1}$ showed maximum enhancement in

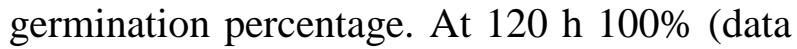
in the parenthesis) germination was achieved under all three salinity stress levels. Similar result was reported in wheat by Ozhan and Hajibabaei (2013) that $\mathrm{GA}_{3}$ treatments increased germination percentage under salinity stress condition. $\mathrm{GA}_{3}$ involved in biosynthesis and secretion of $\alpha$-amylase enzyme in plants hydrolyzing starch into simpler sugar thereby enhancing germination percentage.

\section{Germination index}

Germination index was negatively affected by salt $(\mathrm{NaCl})$ stress, a general trend of decrease in germination index was found with increase in salinity. It was found that $\mathrm{NaCl}$ at the mild (50 $\mathrm{mM})$ and moderate (75) levels showed less reduction with the tune of $(5 \%)$ and $(14 \%)$ respectively as compared to and severe (100 $\mathrm{mM}$ ) concentration with the reduction of $(30 \%)$. The result is in agreement with that obtained by Behairy et al., (2012) who reported that in fenugreek seeds speed of germination was significantly reduced in direct relation to the increasing salinity level, an effect that could possibly be due to reduced seeds metabolism and water absorption.

Application of wheat seeds with AsA and $\mathrm{GA}_{3}$ significantly increased the speed of germination under saline condition. In case of AsA treated seeds under all the three salinity levels, the application of $100 \mathrm{mg} \mathrm{L}^{-1}$ AsA showed maximum increase. Similar result was presented by Mohsen et al., (2014) that soaking of seeds in ascorbic acid alleviates the adverse effects of the higher salinity levels on the speed of germination.

This was due to its possible utility as an organic substrate for respiratory energy metabolism that helps in stress tolerance and increased speed of germination. Under all three stress condition seeds treated with $\mathrm{GA}_{3}$ @ $250 \mathrm{mg} \mathrm{L}^{-1}$ was the best in nullifying the adverse effect of salt stress on speed of germination. Stimulation of germination index by $\mathrm{GA}_{3}$ might be due to $\mathrm{GA}_{3}$-induced inhibition of $\mathrm{Na}^{+}$accumulation with a concomitant increase in $\mathrm{K}^{+}$accumulation in radicle and plumule. $\mathrm{GA}_{3}$ plays crucial role in imbibition by decreasing the density of cytoplasm and hence, increasing water absorption and increasing germination percentage as evident in the present investigation also. 


\section{Seed moisture percentage}

It sharply decreased with increasing salinity levels. The higher concentration $(100 \mathrm{mM})$ showed more reduction (24\%) as compared to mild $(50 \mathrm{mM})$ and moderate $(75 \mathrm{mM})$ concentrations where the reduction was to the tune of $(7 \%)$ and $(13 \%)$ respectively, as compared to control. El Goumi et al., (2011) also stated that increasing salinity caused the diminution of water content in the seeds, roots and the shoots for all cultivars of wheat; and the reduction of water content was the most noticeable with highest $\mathrm{NaCl}$ level. The highest seed moisture content of AsA treated seeds were found with its moderate concentration and treatment of wheat seeds with $\mathrm{GA}_{3}$, its highest concentration showed greatest seed moisture content. Abou-Leila et al., (2012) also revealed that when jatropha plants were treated with AsA under different salt concentrations $(4000,8000$ and 12000 $\mathrm{ppm})$ there was an increase in relative water content and osmotic pressure through osmotic adjustment. Relative water content percentage (RWC) and osmotic potential also increased as the concentration of ascorbic acid increased.

This increase in water content may be attributed to the increase in accumulation of osmolytes under the influence of added AsA which maintained the water potential, thereby moisture content of seed. The result may also be due to the fact that hormones generally decrease the viscosity of cytoplasm and increase diffusion of water into the cell.

\section{Root to shoot length ratio}

A progressive increase in root to shoot length ratio was found with increase in salinity levels. Severe stress forced more increase of root/shoot length ratio with the tune of $(10 \%)$, as compared to moderate (22\%) and mild stress $(25 \%)$ conditions. The result is in accordance with Hameed et al., (2008).
Application of AsA and $\mathrm{GA}_{3}$ were found to increase the root to shoot length ratio under salinity stress levels. For the seeds pretreated with AsA under all stress levels, the maximum increment was found with the application of highest level of AsA. Rafique et al., (2011) also reported that application of $15 \mathrm{mg} \mathrm{L}^{-1}$ AsA showed enhanced root/shoot length ratio under saline condition.

Under mild and moderate stress condition, $\mathrm{GA}_{3} @ 150$ and $250 \mathrm{mg} \mathrm{L}^{-1}$ were effective in nullifying the adverse effect of salt stress on root to shoot length ratio. However, under severe stress $\mathrm{GA}_{3} @ 200 \mathrm{mg} \mathrm{L}^{-1}$ showed best result. This result was justified by the fact that both AsA and $\mathrm{GA}_{3}$ regulates physiological and biochemical activities in plants and can be used as a potential growth promoter to improve root growth more than the shoot growth under saline conditions, thereby increasing root to shoot length ratio.

\section{Root/shoot fresh weight ratio}

Salinity $(\mathrm{NaCl})$ stress had an overall adverse effect on root to shoot fresh weight ratio as the same decreased progressively with increasing salinity levels. Khavarinegad et al., (2014) and James et al., (2006) also observed similar results in lentil and Sarcobatus vermiculatus respectively. This damage could be attributed to reduction in water availability, toxicity of specific ions, and nutritional imbalance caused by such ions. These effects might inhibit the root growth more which was in direct contact with salt then the shoot growth. Remarkable increase in root to shoot fresh ratio was found after pretreatment of wheat seeds with ascorbic acid and gibberellic acid under saline condition. It was found that seeds pretreated with AsA @ $50 \mathrm{mg} \mathrm{L}^{-1}$ showed best increment under mild and severe stress conditions. Under moderate stress level treatment with AsA at its highest concentration $\left(150 \mathrm{mg} \mathrm{L}^{-1}\right)$ was more effective. 
Table.1 Effect of $\mathrm{NaCl}$ induced salinity stress, ascorbic acid (AsA) and gibberellic acid (GA3) on seed germination (arc sign) at 24, 48, 72, 96 and $120 \mathrm{~h}$ after germination of wheat. The data were transformed using arc sign transformation

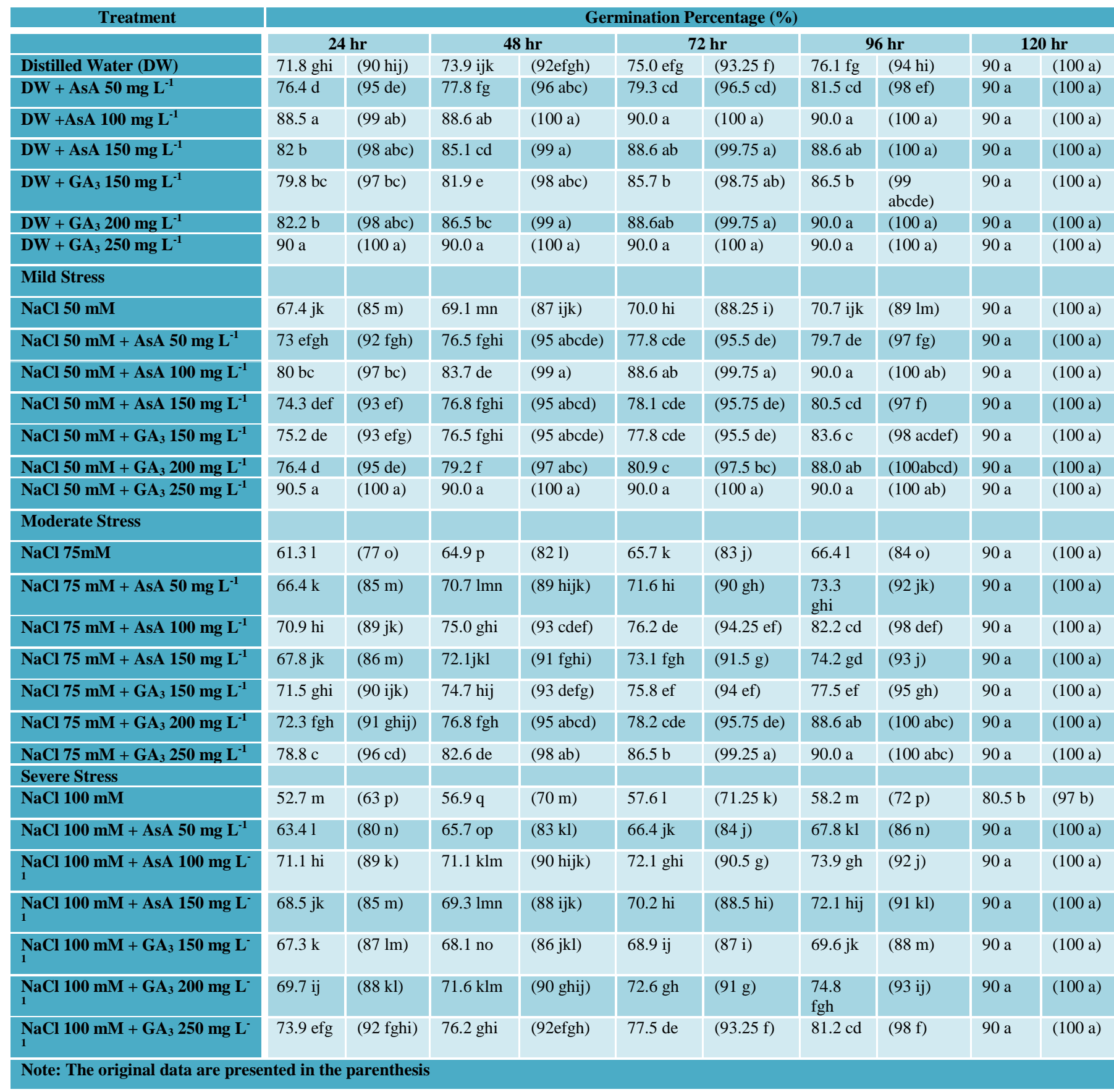


Table.2 Effect of $\mathrm{NaCl}$ induced salinity stress, ascorbic acid (AsA) and gibberellic acid $\left(\mathrm{GA}_{3}\right)$ on speed of germination at $24 \mathrm{~h}$ after germination of wheat

\begin{tabular}{|c|c|c|c|}
\hline Treatments & $\begin{array}{c}\text { Speed of } \\
\text { Germination }\end{array}$ & Treatments & $\begin{array}{c}\text { Speed of } \\
\text { Germination }\end{array}$ \\
\hline Distilled Water & $24 \mathrm{~h}$ & Mild Stress & $24 \mathrm{~h}$ \\
\hline Distilled Water (DW) & 3.8 hij & $\mathrm{NaCl} 50 \mathrm{mM}$ & $3.6 \mathrm{~m}$ \\
\hline DW + AsA $50 \mathrm{mg} \mathrm{L}^{-1}$ & $3.9 \mathrm{de}$ & $\mathrm{NaCl} 50 \mathrm{mM}+\mathrm{AsA} 50 \mathrm{mg} \mathrm{L}^{-1}$ & 3.8 fghi \\
\hline DW +AsA $100 \mathrm{mg} \mathrm{L}^{-1}$ & $4.1 \mathrm{ab}$ & $\mathrm{NaCl} 50 \mathrm{mM}+\mathrm{AsA} 100 \mathrm{mg} \mathrm{L}^{-1}$ & $4.1 \mathrm{bc}$ \\
\hline $\mathrm{DW}+\mathrm{AsA} 150 \mathrm{mg} \mathrm{L}^{-1}$ & $4.1 \mathrm{abc}$ & $\mathrm{NaCl} 50 \mathrm{mM}+$ AsA $150 \mathrm{mg} \mathrm{L}^{-1}$ & $3.9 \mathrm{efg}$ \\
\hline $\mathrm{DW}+\mathrm{GA}_{3} 150 \mathrm{mg} \mathrm{L}^{-1}$ & $4.0 \mathrm{c}$ & $\mathrm{NaCl} 50 \mathrm{mM}+\mathrm{GA}_{3} 150 \mathrm{mg} \mathrm{L}^{-1}$ & 3.9 ef \\
\hline $\mathrm{DW}+\mathrm{GA}_{3} 200 \mathrm{mg} \mathrm{L}^{-1}$ & $4.1 \mathrm{abc}$ & $\mathrm{NaCl} 50 \mathrm{mM}+\mathrm{GA}_{3} 200 \mathrm{mg} \mathrm{L}^{-1}$ & $3.9 \mathrm{de}$ \\
\hline $\mathrm{DW}+\mathrm{GA}_{3} 250 \mathrm{mg} \mathrm{L}^{-1}$ & $4.2 \mathrm{a}$ & $\mathrm{NaCl} 50 \mathrm{mM}+\mathrm{GA}_{3} 250 \mathrm{mg} \mathrm{L}^{-1}$ & $4.2 \mathrm{a}$ \\
\hline Treatments & $\begin{array}{c}\text { Speed of } \\
\text { Germination }\end{array}$ & Treatments & $\begin{array}{c}\text { Speed of } \\
\text { Germination }\end{array}$ \\
\hline Moderate Stress & $24 \mathrm{~h}$ & Severe Stress & $24 \mathrm{~h}$ \\
\hline $\mathrm{NaCl} 75 \mathrm{mM}$ & $3.2 \mathrm{o}$ & $\mathrm{NaCl} 100 \mathrm{mM}$ & $2.6 \mathrm{p}$ \\
\hline $\mathrm{NaCl} 75 \mathrm{mM}+$ AsA $50 \mathrm{mg} \mathrm{L}^{-1}$ & $3.5 \mathrm{~m}$ & $\mathrm{NaCl} 100 \mathrm{mM}+\mathrm{AsA} 50 \mathrm{mg} \mathrm{L^{-1 }}$ & $3.3 \mathrm{n}$ \\
\hline $\mathrm{NaCl} 75 \mathrm{mM}+$ AsA $100 \mathrm{mg} \mathrm{L}^{-1}$ & $3.7 \mathrm{jk}$ & $\mathrm{NaCl} 100 \mathrm{mM}+$ AsA $100 \mathrm{mg} \mathrm{L}{ }^{-1}$ & $3.7 \mathrm{jk}$ \\
\hline $\mathrm{NaCl} 75 \mathrm{mM}+\mathrm{AsA} 150 \mathrm{mg} \mathrm{L}^{-1}$ & $3.6 \mathrm{~m}$ & $\mathrm{NaCl} 100 \mathrm{mM}+$ AsA $150 \mathrm{mg} \mathrm{L}^{-1}$ & $3.6 \mathrm{im}$ \\
\hline $\mathrm{NaCl} 75 \mathrm{mM}+\mathrm{GA}_{3} 150 \mathrm{mg} \mathrm{L}^{-1}$ & $3.8 \mathrm{ijk}$ & $\mathrm{NaCl} 100 \mathrm{mM}+\mathrm{GA}_{3} 150 \mathrm{mg} \mathrm{L}^{-1}$ & $3.5 \mathrm{~m}$ \\
\hline $\mathrm{NaCl} 75 \mathrm{mM}+\mathrm{GA}_{3} 200 \mathrm{mg} \mathrm{L}^{-1}$ & 3.8 ghij & $\mathrm{NaCl} 100 \mathrm{mM}+\mathrm{GA}_{3} 200 \mathrm{mg} \mathrm{L}^{-1}$ & $3.7 \mathrm{kl}$ \\
\hline $\mathrm{NaCl} 75 \mathrm{mM}+\mathrm{GA}_{3} 250 \mathrm{mg} \mathrm{L}^{-1}$ & $4.0 \mathrm{bcd}$ & $\mathrm{NaCl} 100 \mathrm{mM}+\mathrm{GA}_{3} 250 \mathrm{mg} \mathrm{L}^{-1}$ & $3.8 \mathrm{fgh}$ \\
\hline Effect & C.V. $(\%)$ & \multicolumn{2}{|c|}{\begin{tabular}{c|c} 
S.Em. \pm & CD at $(0.05)$
\end{tabular}} \\
\hline SALT x GRT & 8.5 & \multicolumn{2}{|c|}{0.011} \\
\hline
\end{tabular}

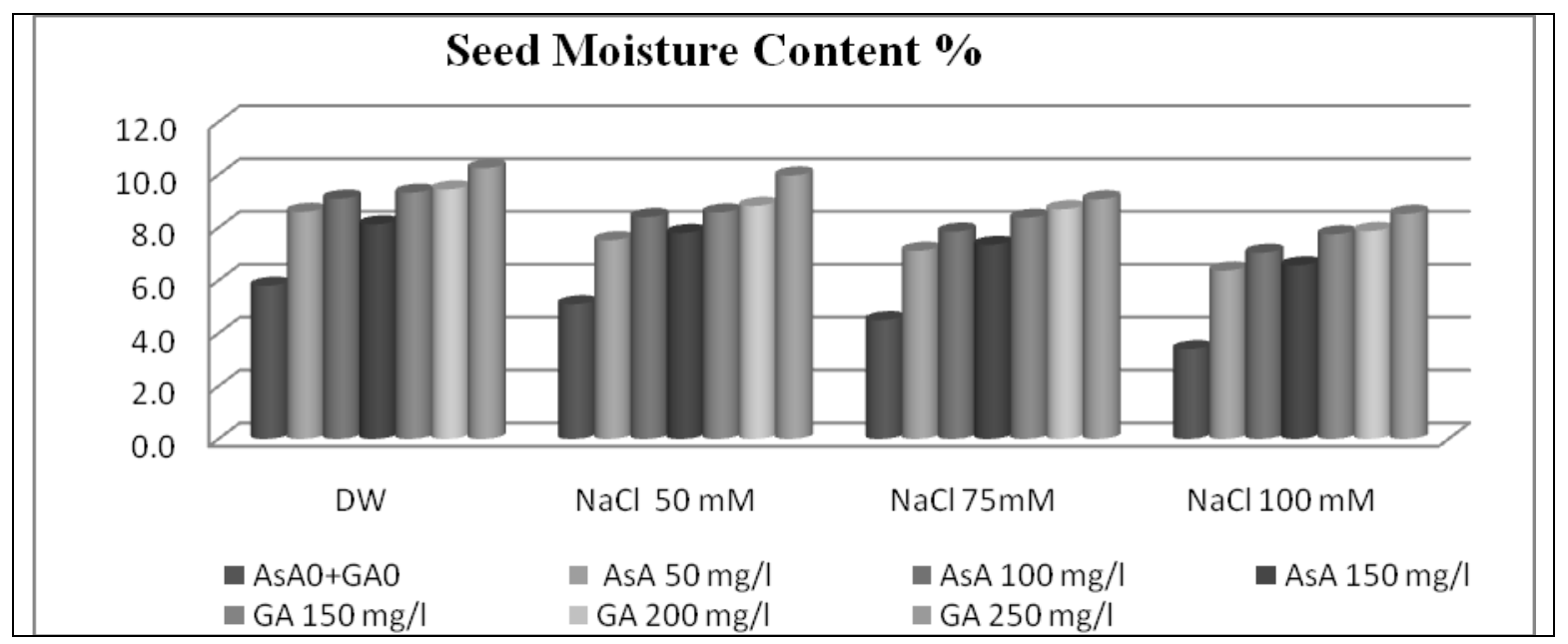



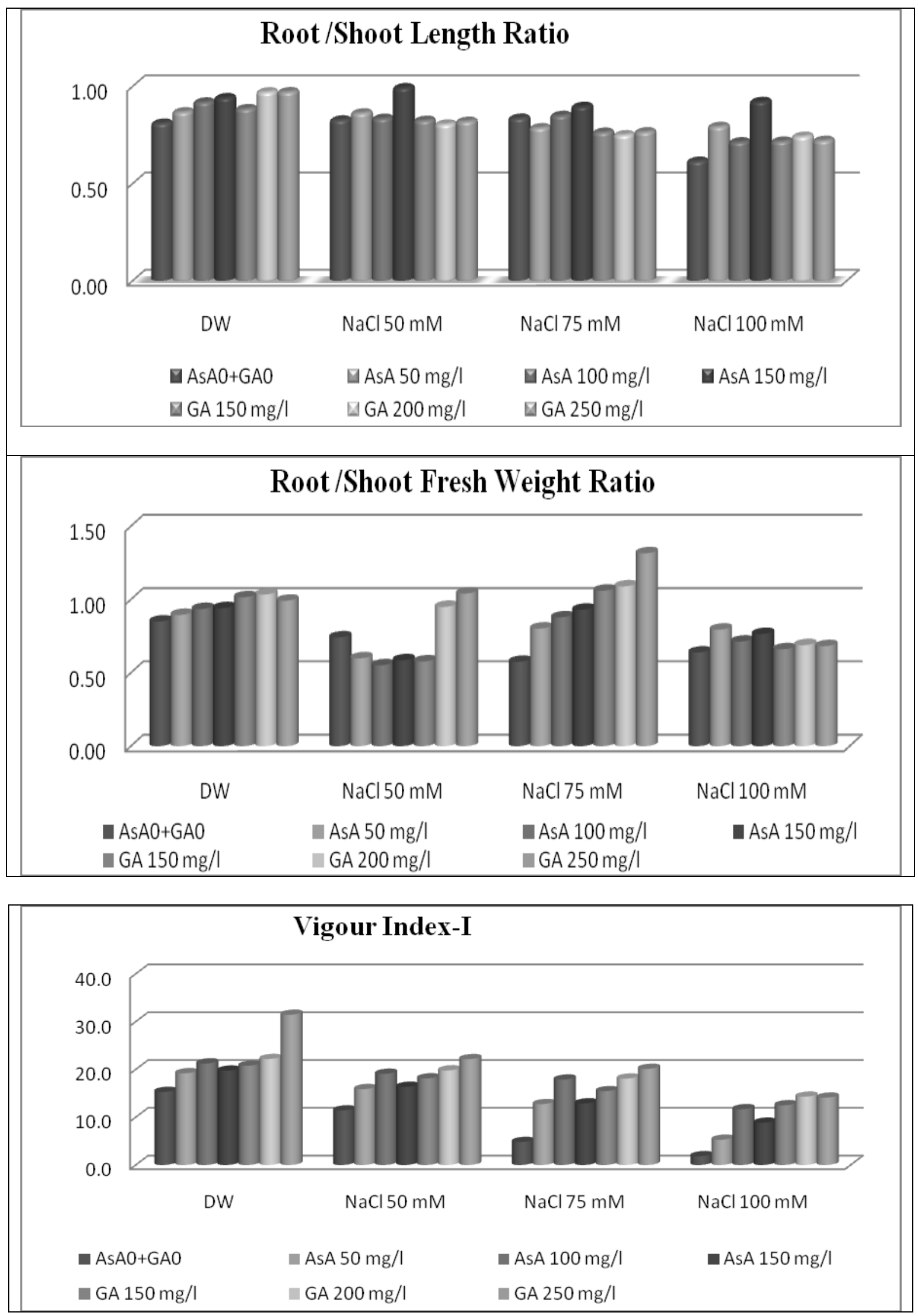


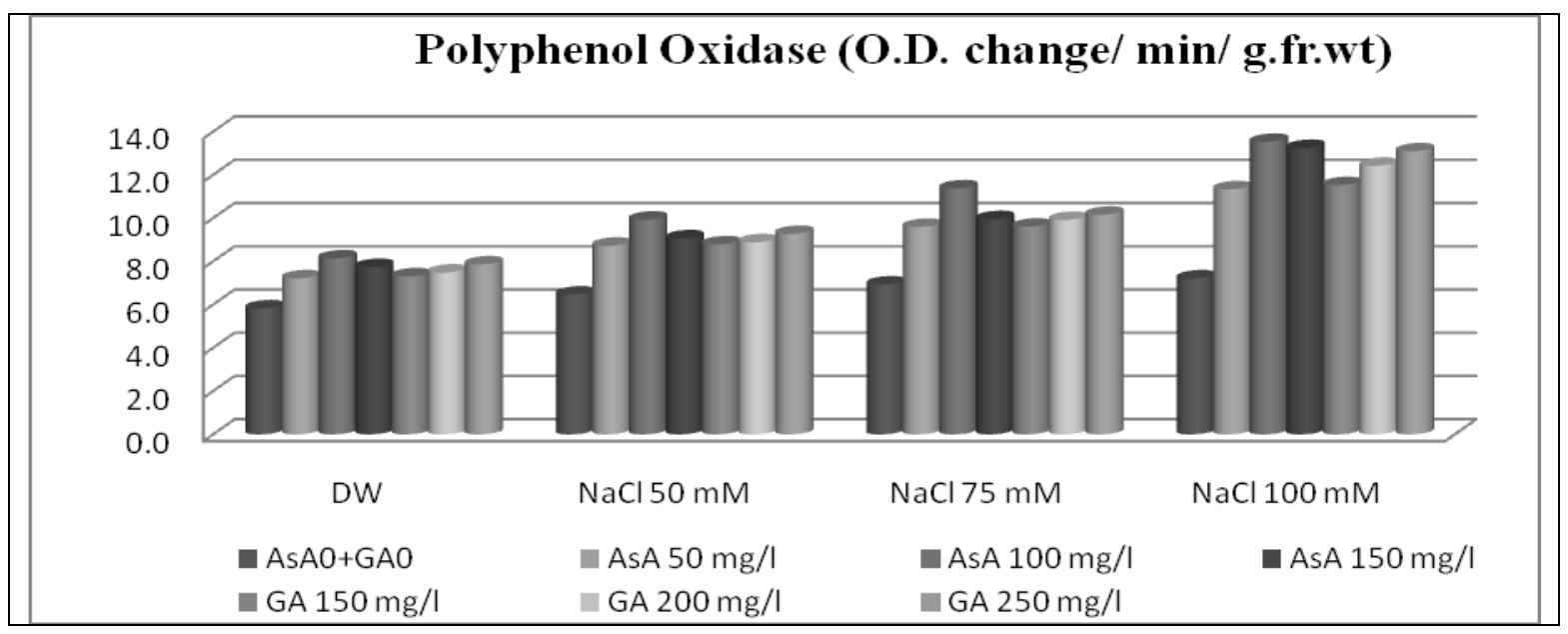

With respect to the treatment of wheat seeds with $\mathrm{GA}_{3}$ under mild and moderate stress condition, the maximum increment was shown by its treatment at highest concentration $\left(250 \mathrm{mg} \mathrm{L}^{-1}\right)$. Seeds treatment with mild concentration of $\mathrm{GA}_{3}\left(200 \mathrm{mg} \mathrm{L}^{-1}\right)$ performed well under severe stress condition. Similar report was reported by Khavarinegad et al., (2014) who showed that pre-treatment of lentil seeds with $\mathrm{GA}_{3}$ increased the root to shoot fresh weight ratio under saline condition.

\section{Vigour index I}

A progressive increase in salinity levels effectively reduced the vigour index $\mathrm{I} . \mathrm{NaCl}$, at the moderate and severe levels showed maximum reduction of $(31 \%)$ and $(34 \%)$ respectively as compared to mild stress (59\%) levels. The result is supported by Mosavian and Eshraghi (2013) and Elouaer et al., (2012). The reduction in seedling vigour may be due to reduced germination percent observed in the present investigation. An increase in vigour index I was found after pretreatment of wheat seeds with ascorbic acid and gibberellic acid under saline condition. Application of AsA @ $100 \mathrm{mg} \mathrm{L}^{-1}$ was the best under all levels of salinity. The result is supported by Ghoohestani et al., (2012) who reported that seeds priming of tomato with salicylic acid and ascorbic acid resulted in increased vigour index I under salt stress concentration. Ascorbic acid protects metabolic processes against $\mathrm{H}_{2} \mathrm{O}_{2}$ and other toxic derivatives of oxygen which affect many enzyme activities, minimizes the damage caused by oxidative processes through synergistic function with other antioxidants, and stabilizes membranes (Agarwal and Pandey, 2004 and Sairam et al., 2005). All salinity levels under application of $250 \mathrm{mg} \mathrm{L}^{-1} \mathrm{GA}_{3}$ exhibited increased vigour index. Enhanced germinative parameters in response to $\mathrm{GA}_{3}$ application have led to increased seedling vigour.

\section{Polyphenol oxidase activity}

PPO activity increased considerably with increasing salinity levels. Slight induction $(15 \%)$ in the given parameter was observed under mild salt stress level. However, at moderate and severe stress levels more than double increase of $36 \%$ and $38 \%$ were observed. Similar result was reported by Sairam et al., (2005) in wheat.

A noticeable increase in polyphenol oxidase activity was observed after pretreatment of wheat seeds with ascorbic acid and gibberellic acid under saline condition. Seeds pretreated with AsA @ 100 mg L ${ }^{-1}$ was numerically the 
best and treatment of AsA @ 150 mg L ${ }^{-1}$ was at par with it under all three stress condition. The result is in agreement with Elhamid et al., (2014) in wheat cultivar.

AsA-induced enhanced salt tolerance in wheat plants was due to having a better antioxidant system as found in the present investigation for the effective removal of ROS plants, and maintenance of ion homeostasis. Application of the highest concentration $\mathrm{GA}_{3}\left(250 \mathrm{mg} \mathrm{L}^{-1}\right)$ under all three stress conditions, showed maximum increase in PPO activity. Thus, it could be inferred that PPO plays a vital role in plant defense against oxidative stress by scavenging $\mathrm{H}_{2} \mathrm{O}_{2}$ in chloroplast, cytosol, mitochondria and peroxisome of plant cells. Among the two biostimulators, seeds treatment with AsA @ $100 \mathrm{mg} \mathrm{L}^{-1}$ was the best in ameliorating the adverse effect of salinity and increased polyphenol oxidase activity.

Salinity stress $(\mathrm{NaCl})$ at moderate and severe levels (75 and $100 \mathrm{mM}$ ) showed more reduction in almost all germination parameters and some biochemical parameters viz., seed moisture content, germination percentage, germination index, root/shoot length ratio, root/shoot fresh weight ratios and vigour index-I as compared to salinity stress at mild level $(50 \mathrm{mM})$ during all the periods of germination. However, salinity stress at all three levels (50, 75 and $100 \mathrm{mM}$ ) enhanced root/shoot length ratio and antioxidants viz., polyphenol oxidase activity. Thus, distinct favorable effect of ascorbic acid and gibberellic acid in alleviation of salinity stress could be discerned as evidenced by activated physiological parameters and metabolism of germinating seedlings of wheat after pretreatment under saline condition. Hence, this study proves the role of these biostimulators in ameliorating the deleterious effect of salinity stress (Table 1 and 2).

\section{Future prospects}

The present study paves the way for use of Ascorbic acid and Gibberellic acid at germination stage of crop to overcome the low productivity of crops under salinity stress. The present work throws light on the development of physiological and biochemical resistance in the crop as a result of presoaking treatment of the growth stimulator Ascorbic Acid and growth hormone Gibberellic acid which counter the effect of salinity stress. The yield losses could be minimized by conferred resistance against salinity stress and the physiological and biochemical markers conferring resistance could be used in further crossing programs to select resistant lines.

\section{References}

Abdelfattah, M. A., Shahid, S. A. and Othman, Y. R. 2009. Soil salinity mapping model developed using RS and GIS-A case study from Abu Dhabi, United Arab Emirates. Eur J Sci Res., 26: 342-351.

Abdul- baki, A. A. and Anderson, J. D. 1973. Vigour determination in soybean seed by multiplication. Crop Science. 3: 630633.

Abo-Kassem, E. E. M. 2007. Effects of salinity: Calcium interaction on growth and nucleic acid metabolism in five species of Chenopodiaceae. Turk. $J$. Bot., 31: 125-134.

Abou-Leila, B., Metwally, S. A., Hussen, M. M., and Leithy, S. Z. 2012. The combined effect of salinity and ascorbic acid on anatomical and physiological aspects of Jatropha plants. Australian Journal of Basic and Applied Sciences. 6(3): 533-541.

Afzal, I., Basra, S. M., Farooq, M., and Nawaz, A. 2006. Alleviation of salinity stress in spring wheat by hormonal 
priming with $\mathrm{ABA}$, salicylic acid and ascorbic acid. Int. J. Agric. Biol., 8(1), 23-28.

Agarwal, S., and Pandey, V. 2004. Antioxidant enzyme responses to $\mathrm{NaCl}$ stress in Cassia angustifolia. Biologia Plantarum. 48(4):555-560.

Akbarimoghaddam, H., Galavi, H. M., Ghanbari, A. and Panjehkeh, N. 2011. Salinity effects on seed germination and seedling growth of bread wheat cultivars. Trakia J. Sci.., 9(1): 43-50.

Alonso-Ramírez, A., Rodríguez, D., Reyes, D., Jiménez, A.J., Nicolás, G., LópezCliment, M., Gómez-Cadenas, A., and Nicolás, C. 2009. Evidence for a role of gibberellins in salicylic acid-modulated early plant responses to abiotic stress in Arabidopsis seeds. Plant Physiology. 150: 1335-1344.

Azooz, M. M., Alzahrani, A. M., and Youssef, M. M. 2013. The potential role of seed priming with ascorbic acid and nicotinamide and their interactions to enhance salt tolerance in broad bean (Vicia faba L.). Aust J Crop Sci., 7(13): 2091-2100.

Batool, E. J. A. Z., Sajid, Z. A., \& Aftab, F. 2012. Effect of exogenous application of ascorbic acid on antioxidant enzyme activities, proline contents, and growth parameters of Saccharum spp. hybrid cv. HSF-240 under salt stress. Turkish Journal of Biology. 36(6): 630-640.

Behairy, R. T., El-Danasoury, M., \& Craker, L. 2012. Impact of ascorbic acid on seed germination, seedling growth, and enzyme activity of salt-stressed fenugreek. Journal of Medicinally Active Plants. 1(3): 5.

Datta, J. K., Nag, S., Banerjee, A., and Mondai, N. K. 2009. Impact of salt stress on five varieties of Wheat (Triticum aestivum L.) cultivars under laboratory condition. Journal of Applied Sciences and Environmental
Management. 13: (3).

El Goumi, Y., Fakiri, M., Lamsaouri, O., and Benchekroun, M. 2011. Salt stress effect on seed germination and some physiological traits in three Moroccan barley (Hordeum vulgare L.) cultivars. Annals of Biological Research. 2(4): 490-97.

Elhamid, E. M. A., Sadak, M. S., and Tawfik, M. M. 2014. Alleviation of adverse effects of salt stress in wheat cultivars by foliar treatment with antioxidant 2changes in some biochemical aspects, lipid peroxidation, antioxidant enzymes and amino acid contents. Agricultural Sciences. 5(13): 1269.

Elouaer, M. A., and Hannachi, C. 2012. Seed priming to improve germination and seedling growth of safflower (Carthamus tinctorius) under salt stress.Eurasian J. Biosci, 6: 76-84.

El-Tayeb, M. A. 2005. Response of barley grains to the interactive effect of salinity and salicylic acid. Plant Growth Regulation., 45: 215-224.

Ghoohestani, A., Gheisary, H., Zahedi, S. M., and Dolatkhahi, A. 2012. Effect of seed priming of tomato with salicylic acid, ascorbic acid and hydrogen peroxideon germination and plantlet growth in saline conditions. Int. J. Agron. Plant Prod., 3: 700-704.

Hameed, A., Naseer, S., Iqbal, T., Syed, H., and Haq, M. A. 2008. Effects of $\mathrm{NaCl}$ salinity on seedling growth, senescence, catalase and protease activities in two wheat genotypes differing in salt tolerance. Pak. J. Bot.., 40(3): 10431051.

Iqbal M, Ashraf M,Jamil A and ur-Rehman S. 2006. Does seed priming induce changes in the levels of some endogenous plant hormones in hexaploid wheat plants under salt stress. J. Integr. Plant Biol.., 48: 181-189.

ISTA. 1985. International Rules for Seed 
Testing Rules. Seed Sci Technol., 13: 299-55.

James, J. J., Alder, N. N., Muhling, K. H., Lauchli, A. E., Shackel, K. A., Donovan, L. A. and Richards, J. H. 2006. High apoplastic solute concentrations in leaves alter water relations of the halophytic shrub, Sarcobatus vermiculatus. J. Exp. Bot., 57:139-147.

Kabar, K., and Baltepe, S. 1987. Alleviation of salinity stress on germination of barley seeds by plant growth regulators. Turkish Journal of Biology. 11:108-117. Khavarinegad, R. A., Safari, Z., and Kian, S. 2014. The effect of gibberellic acid $\left(\mathrm{GA}_{3}\right)$ on seed germination and early growth of lentil seedlings under salinity stress. Middle-East Journal of Scientific Research., 19(7), 995-1000.

Maguire, J. D. 1962. Speed of germination aid in selection and evaluation for seedling emergence and vigour. Crop Science., 2: $176-177$.

Malik, C. P., and Singh, M. B. 1980. Plant enzymology and Histienzymology. Kalyani publishers, New Delhi 110002.

Mohsen, A. A., Ebrahim, M. K. H., and Ghoraba, W. F. S. 2013. Effect of salinity stress on Vicia faba productivity with respect to ascorbic acid treatment. Iranian Journal of Plant Physiology. 3(3), 725-736.
Mosavian, S. N., and Eshraghi N. M. 2013. The effects of seed size and salinity on seed germination characteristic in wheat (var. Chamran). International Journal of Farming and Allied Sciences. 2(2): 1379-1383.

Ozhan, N., and Hajibabaei, M. 2013. Studies on effectiveness of plant phytohormones in reduction of salinity effects on germination of some cultivar of spring wheat. International Journal of Agronomy and Plant Production., 4(8), 1863-1874.

Pedranzani, H., Racagni, G., Alemano, S., Miersch, O., Ram'Irez, I., PeNa-Corts, H., Taleisnik, E., Machado-Domenech, E. and Abdala, G. 2003. Salt tolerant tomato plants show increased levels of jasmonic acid. Plant Growth Regulation. 41: 149-158.

Rafique, M., Raza, S. H., Qasim, M. and Iqbal, N. 2011. Pre-sowing application of ascorbic acid and salicylic acid to seed of pumpkin and seedling response to salt. Pakistan J. of Botany., 43(6): 2677-2682.

Sairam, K. R., Agarwal, S., Srivastava, G. C., Aruna, T. and Meena, C. R. 2005. Role of ABA, salicylic acid, calcium and hydrogen peroxide on antioxidant enzymes induction in wheat seed lings. Plant Sci.., 169, 559-570.

\section{How to cite this article:}

Neelambari, Chetanaben Mandavia and Sree Ganesh, S. 2018. Curative Effect of Ascorbic Acid and Gibberellic Acid on Wheat (Triticum astivum L.) Metabolism under Salinity Stress. Int.J.Curr.Microbiol.App.Sci. 7(01): 522-533. doi: https://doi.org/10.20546/ijcmas.2018.701.063 